ARAŞTIRMA / ARTICLE

\title{
Kentsel Dönüşüm Uygulamalarında Kurumsal Kapasite Yaratmanın Önemi
}

\section{The Importance of Institutional Capacity Creating in Urban Transformation Processes}

\author{
D Yavuzalp Tüfekçi, ${ }^{1}$ (D) Elif Alkay ${ }^{2}$
}

${ }^{1}$ T.C. Kocaeli Valiliği Çevre ve Şehircilik İI Müdürlüğü

${ }^{2}$ İstanbul Teknik Üniversitesi, Şehir ve Bölge Planlaması Bölümü, İstanbul

ÖZ

6306 sayılı Afet Riski Altındaki Alanların Dönüştürülmesi Hakkında Kanun tüm kentsel alanları kentsel dönüşüme konu haline getirmiştir. Merkez yetkisindeki yasanın uygulanması yetki devri ile yerel yönetimlere bırakılmıştır. Kentsel dönüşüm gibi oldukça karmaşık ve çok aktörlü, beklenen sonuçları çok boyutlu olan bir planlama eyleminde kurumların kendini buna karşılık verecek şekilde yeniden yapılandırması kaçınılmaz denilebilir. Kurumsal yeniden yapılandırmanın hedefteki planlama eylemi doğrultusunda nasıl yapılacağı; bu yapının kapasite ve yapabilirliğinin nasıl sağlanacağı; bu yapının farklı kurum ve organizasyonlarla, problem kapsamındaki aktörlerle ilişki ağlarını nasıl kuracağı; bu yapının süresi-sürekliliğinin ne olacağı önem kazanan sorulardır. Bu doğrultuda, bu araştırmanın amacı, yerel yönetimlerin bu süreci yürütebilecek etkin ve yetkinlikte bir kurumsal kapasite yaratabilme kabiliyetlerinin sorgulanmasıdır. Sorgulama üç farklı büyük şehir belediyesi ile derinlemesine mülakatlar yoluyla yapılmıs ve bulgular tartışmaya açılmıştır.

Anahtar sözcükler: Kentsel dönüşüm; kurumsal kapasite; Türkiye.

\section{ABSTRACT}

Law Regarding the Transformation of Areas under Risk of Disaster (Law No: 6306 enacted in 2012) made all urban areas subject to urban transformation. Although the Ministry was principal authority, implication process was delegated to the responsibility of local authorities. In order to achieving implication processes, local authorities have to being restrucured institutionally and creating institutional capacities. Some concerns have been arisen in restructuring process that those, eventually, define the method of the capacity creating in order to succeed the targeted transformation action in the targeted area. Concerns are upon those questions: what is the way of establishing institutional capacity? What is the way of setting institutional strategic vision in order to achieving targeted urban transformation? What is the way of setting relations between the institution and other related institutions? What is the way of setting relations between the institution and actors involved in the transformation process? In that context, the aim of this research is to investigate the capabilities of local authorities in institutional restructuring and institutional capacity creating. Investigation was done by face-to-face interviews with three different metropolitan municipalities and evidences were discussed consistent with theoretical background.

Keywords: Urban transformation; institutional capacity creating; Turkey.
Geliş tarihi: 23.04.2018 Kabul tarihi: 08.01.2019

Online yayımlanma tarihi: 06.04.2019

İletişim: Elif Alkay.

e-posta: alkayel@itu.edu.tr
TMMOB

Şehir Plancıları Odası 


\section{Giriş}

2012 yılında yürürlüğe giren 6306 sayılı Afet Riski Altındaki Alanların Dönüştürülmesi Hakkında Kanun (R.G. No. 28309, 2012) ile birlikte tüm kentler kentsel dönüşüm eylemlemine konu haline gelmiştir. Bu sadece çok büyük ölçekli bir mekânsal operasyon değil aynı zamanda sonuçları çok boyutlu bir yeniden yapılandırma eylemidir. Adı geçen yasa merkez yetkisinde bir yasa olmakla birlikte, uygulama süreci, yetki aktarımıyla birlikte, mevcut kurumlar, diğer bir deyişle, yerel yönetimler tarafından yürütülmektedir. Bu durum önemli bir soruyu beraberinde getirmektedir: yerel yönetimler bu süreci yürütebilecek etkinlikte ve yetkinlikte kurumsal kapasiteye sahip midir?

Bu çalışmada kurumsal kapasite yerel yönetimlerin 6306 sayılı yasa doğrultusunda iş ve işlemleri geniş kapsamlı olarak yapma ve yürütme süreçlerinde kurumsal yeniden yapılandırma modelleri olarak ele alınmıştır. Etkin ve yönlendirici bir kurumsal kapasitenin kentsel dönüşüm sürecinin bir eylemler bütünü olarak yürütülmesinde ve toplumsal ve ekonomik faydaların yerel kalkınma yaratmasında temel araç olduğu kabul edilmiştir (Tüfekçi, 20I7). Bu bağlamda, yüksek kurumsal kapasite şöyle tariflenmiştir: kentsel dönüşümü planlama geniş anlamı çerçevesinde kavramsal olarak tartışabilen, yapma ve uygulama süreçlerinde geniş katılımın sağlanması yönünde modeller geliştirebilen, alansal ve parsel bazlı uygulamalara dönük alternatif dönüştürme modellerini tartışmaya açabilen, yasayı dar anlamı ve uygulamalarından çıkararak yerel kaynak kullanımlarını harekete geçirecek ve yerel kalkınmada katalizör görevi üstlenebilecek modeller üretebilen, tüm bunların top yekûn uygulamasını yapabilen, ilaveten, kurumsal bilgi birikimi ve uygulama pratiğini diğer kurumlarla paylaşabilen etkinlik ve yetkinlikte yerel yönetimler (Healey vd., 2002; Healey vd., 2003; Tüfekçi, 2017).

Gualini (2017) kapasite ve yapabilirlik kavramlarının farklı olduğunu vurgular. Yapabilirlik birey ya da grupların bilgi ve yetkinlikleri ile bir işle ilgili olarak salahiyetleri düzeyinde kendilerine tanınan sorumluluklar olarak tanımlanabilir. Kentsel dönüşüm özelinde tanımlamaya çalışırsak, sürecin kapsamlı ve bütünleşik olarak ve planlama geniş anlamı içinde sistemsel olarak kurgulanabilmesi ve yönetilebilmesidir. Kapasite ise bireylerin ya da grubun yürütülmesi gereken süreçte toplam yetkinliğidir. Bireylerin yetkinlikleri ötesinde, yapılacak işin büyüklüğü, bu işi gerçekleştirmek üzere kullanılabilecek kaynaklar ve tarif edilen iş için çizilen çerçeve içinde ne düzeyde hareket etme özgürlüğüne sahip oldukları önem kazanır. Dolayısıyla, bir kurumda kapasite olarak yetkin birey ya da birey topluluğunun bulunması, kurumun belirlenen işle ilgili kurumsal strateji ve politikaları kurgulanmadıkça, tarif edilen ya da yapılması beklenen işi başarıyla yürütebilecekleri anlamına gelmez (Gualini, 20I7). Kurumsal yapı içinde yeniden düzenlemelerle oluştu- rulmuş birimler, bu birimlerin konu özelinde seminerler, çaışma programları vb. ile bilgilerinin artırılması, konu özelinde araştırma projelerinin desteklenmesi ve bu projelerde etkin rol alınması, kurum içi bilgi bankasının oluşturulması, farklı kurumlardaki benzer birimlerle kurulacak bilgi akış-paylaşım ağları, işbirliği programları, bütünleşik yaklaşımın gerektirdiği farklı aktörlerle teması olanaklı kılacak zeminin oluşturulması kurumsal kapasitenin yaratılması konusunda atılması zorunlu adımlardır (de Magalhaes, 2004). Kurumsal yeniden yapılandırmanın temel hedefi farklı kurum ve organizasyonlar ile işbirliği içinde ilgili konuyu her türlü kavramsal durumu içerecek şekilde tartışabilen, bu tartışmalar doğrultusunda kurum politika ve stratejilerini kurgulayabilen, bütünleşik dönüşüm modelleri üretebilen, farklı görüş ve beklentileri eylemin geniş anlamı içinde yorumlayabilen ve bu doğrultuda çözüm önerileri geliştirebilen etkin ve yetkin bir kurumsal kapasite yaratmaktır (Gualini, 2017; de Magalhaes, 2004).

Kentsel dönüşüm yasası yerel yönetim yetkileri üstünde karar geliştiren merkez yetkisinde bir düzenlemedir ancak 6306 sayılı Yasa'nın uygulanması merkezi yönetimin yetki devri ile yerel yönetimlere bırakılmıştır. Farklı ölçeklerde olsa da ülkenin tüm şehirlerinin kentsel dönüşüm eylemine dâhil olması, konunun büyüklüğünü ve yapılan her türlü eylemin, ölçeğinden bağımsız olarak, çarpan etkisinin güçlü olacağını göstermektedir. Bu durumda, böylesine büyük ölçekli bir operasyonu yürütecek birimlerin etkin kurumsal kapasiteye sahip olmaları bir zorunluluk olarak karşımıza çıkmaktadır. Ancak yerel yönetimlerin bu süreci yürütmek üzere yönetim organizasyon yapılanmalarını nası sağlayacakları, öz kaynaklarını nasıl kullanacakları, kurumsal kapasite yaratmak üzere ne tür destekler alabilecekleri, uygulama süreçlerinin ve uygulama sonuçlarının nasıl monitör edileceği konuları belirsizdir ya da yerel yönetimlerin kendi tasarruflarına bırakılmıştır (Tüfekçi, 2017). Bu durum; böylesi büyük ölçekli bir dönüşüm sürecinin planlama eyleminin bir parçası haline gelmesi, geniş kapsamlı tartışılabilmesi, kapsayıcı olması ve etkin kaynak kullanımı bakımından önemli bir problem oluşturmaktadır. Bu doğrultuda, bu araştırmada, kentsel dönüşüm uygulama süreçlerinde etkin rol alan yerel yönetimlerin bu süreci yürütebilmek yönünde bir kurumsal kapasite yaratıp yaratamadıkları ve kurumsal kapasite yaratma süreçlerinde mevcut kurumsal yapının önlerinde bir bariyer teşkil edip etmediği (Zhao, 20I5) sorgulanmıştır. Dolayısıyla, bu sorgulama uygulama süreçlerini yürütecek yerel yönetimlerin bu süreçle baş edebilmek üzere kendi yönetim yapılarında yeniden yapılandırma ve kurumsal kapasite yaratma yönünde attıkları adımları yansıtmayı, diğer bir deyişle, yapısal durumu ortaya koymayı hedeflemektedir.

Yapısal durum analizi, rasyonel analitik kriterlere göre seçilen üç büyük şehir belediyesi ile yerinde yapılan derinlemesine mülakatlara dayanmaktadır. Üç örneğin seçiminde farklı kurum ve kuruluşlarla işbirliği yapmış ve dönüşüm uygulamala- 
rında kendi pratiklerini oluşturmuş yerel yönetimlerin seçimi belirleyici olmuştur (Tüfekçi, 20I7). Mülakatlar ışığında ortaya konan yapısal durum yerel yönetimlerin yasayı hangi kapsamda ele aldıklarının ve kurumsal kapasite oluşturma yaklaşımlarının temel göstergesi olacaktır. Bu analizin merkez yetkileriyle gelen yasaların yerel yönetimlere bırakılan uygulamaları için kurumsal kapasite yaratmanın önemi ve başarı ölçütlerinin neler olabileceğinin sorgulanması konusunda tartışma gündemi oluşturması beklenmektedir.

Çalışmanın izleyen bölümü planlama uygulamalarında kurumsal kapasite konusunu farklı boyutlarıyla tartışan kaynak araştırması bölümüdür. Ayrıca, kentsel dönüşüm uygulamalarında, farklı dünya ülkelerinde kurumsal kapasite yaratılması konusu da örnekler yardımıyla yansıtılmıştır. Bu bölümü araştırmanın yöntemi yanı sıra araştırma bağlamında incelenen üç yerel yönetimin kurumsal kapasite yaratma doğrultusunda yeniden yapılandırma süreçlerinin yansıtıldığı alan araştırması bölümü izlemektedir. Son bölüm ise genel değerlendirme bölümdür.

\section{Kaynak Araştırması}

Kentsel dönüşüm yasası tüm kentleri içeren büyük ölçekli bir yeniden yapılanma eylemini tanımlamaktadır. Healey (I99I) 1980'li yıllar İngiltere'sinde kent politikalarının temelini özel sektör önderliğinde kentsel dönüşümün oluşturduğunu belirtir. Benzer yorumu 2000'li yılların Türkiye'si için de yapmak mümkündür. Öte yandan bu durum planlama eylemi ile entegrasyonu sağlanabilmiş, katılımcı ve kapsamlı bir kentsel dönüşüm süreci olmaktan uzaktır.

Amin ve Thrift (1995) kurumsal kararlılık ve tutarlılığın yerel kalkınmada en önemli araç olduğunu belirtmişlerdir. Ancak güçlü bir kurumsal yapı ile kamu- özel sektör ilişkisi başarıyla kurulabilecek, yerel aktörlerle etkin iletişim ve işbirliği geliştirilebilek, kollektif talep ve beklentiler bireysel beklenti ve çıkarların ötesine geçerek karşılık bulabilecektir. Bunların başarısı ise kaynakların akılcı kullanımı ve işbirliğinden doğan sinerji olacaktır. Kısa ve uzun dönemli toplumsal faydanın yaratılması buna bağlıdır.

Planlama doğası gereği kurumsal bir çevre içinde eylemlerini gerçekleştirir. Kurumlar planlama eylemi için yasa, kural ve normlarla oyun alanını ve bu alanda hareket kabiliyetini belirlerken bir taraftan da sürecin aktörleri için çerçeveyi belirlerler. Dolayısıyla kurumlar doğrudan doğruya ya bu sürecin verimliliğini yükselten ya da tam tersi sınırlayan yapıda olabilirler. Sürecin rasyonel ve verimli işletilebilmesi için planlamanın hedef aldığı konu-problem doğrultusunda kurumsal yeniden yapılandırma gündeme gelebilecektir (Alexander, 2006). Kentsel dönüşüm gibi oldukça karmaşık ve çok aktörlü, beklenen sonuçları çok boyutlu olan bir planlama eyleminde kurumların kendini buna karşılık verecek şekilde yeniden yapılandırması kaçınılmazdır. Temel sorular, yeniden yapılandırmanın hedefteki planlama eylemi doğrultusunda nasıl yapılacağı; bu yapının kapasite ve yapabilirliğinin nasıl sağlanacağı; bu yapının farklı kurum ve organizasyonlarla, problem kapsamındaki aktörlerle ilişki ağlarını nasıl kuracağı; bu yapının süresi-sürekliliğinin ne olacağı şeklinde sıralanabilir.

van der Berg ve Braun (1999) sıralanan sorulara kısmen cevap olabilecek önermelerde bulunmuşlardır. Buna göre, tüm aktörlerin katkı ve desteğini alabilen, bu yolla planlama problemi konusunda yeni fikirleri tartışmaya açabilen, politika ve uygulama araçları geliştirebilen ve tüm bunları bir süreklilik içinde yapabilen yapıların başarılı olma olasılıkları daha yüksek olacaktır. Probleme cevap verecek kurumsal yeniden yapılandırma, hem yönetimin yetki ve sorumluluklarının hem de diğer aktörlerin rol ve sorumluluklarının açıkça tanımlandığı; bir yandan aktörler arasında stratejik ağları geliştirirken öte yandan bu ağların yönetiminin nasıl olacağının belirlendiği, bütünleşik vizyon ve stratejilerin kurgulandı̆̆ı, ilgi (hedef) gruplarının ve daha geniş düzlemde toplumun desteğinin alındığı, politik ve finansal desteğin sağlandığı bir yapı olmalıdır.

Healey vd. (2003)'ne göre, kurumsal kapasite karşılıklı etkileşimler doğrultusunda sürekli olarak kendini yeniden inşa eden, bilgi üretme ve kullanma kapasitesine sahip, bütünü oluşturan farklı aktörleri harekete geçirme potansiyeli taşıyan bir ilişkiler ağı bütünüdür. İlgili planlama problemine çözüm üretebilme, bunu yaparken diyalog kurabilme ve aktörleri olası değişimlere karşı hazırlayarak proaktif tavır takınabilmelerini sağlama (Gupta vd., 20l0) ancak bu şekilde mümkün olacaktır. Bir önemli konu da değişen güncel durum ve problemlere karşı sistemin kendini kaçınılmaz olarak uyumlandırması demektir ki bu kurumun operasyonel yeterlilik ve yapabilirliğinin esasını oluşturur (Buitelaar vd., 2007). Diğer bir deyişle, süreç içinde oluşabilecek olumlu ya da olumsuz her türlü durumu yönetebilmek ve sonuçlarla başa çıkabilmek için uyumlandırma süreci kaçınılmazdır (Gupta vd., 20I0).

Kentsel dönüşümün sadece fiziki mekan üstünde değil toplum üstünde de kısa ve uzun dönemli etkileri olacaktır (Moulaert vd., 2005), dolayısıyla, çok aktörlüdür. Çok aktörlü bu eylemin ilk aşamasından, diğer bir deyişle planlanmasından, uygulamanın sonlanmasına dek işbirlikli katılımcı (Innes ve Booher, 2004; Rydin ve Pennington, 2000) bir süreç izlemesi temel başarı ölçütlerindendir. Kapsamlı ve bütünleşik bir kentsel dönüşümün gerçekleştirilmesi ancak stratejik vizyon ve buna bağlı olarak tanımlanmış kısa dönemli eylemlere bağlıdır. Buradaki kritik nokta bu tanımlamaların yapılması sürecinde farklı aktörlerin sürece ne zaman, nasıl dâhil edilecekleri, aktörler arası çelişen beklentilerin nasıl çözüme ulaştırılacağı (Boons ve Spekkink, 2012) ve sürecin bir bütün olarak nasıl yönetileceğidir. Ayrıca kurumlar arası işbirliğinin (Phelps ve TewdwrJones, 1998) kaçınılmaz olduğu bu süreçte şeffaflık ve uzlaş- 
manın sağlanması esastır. Tüm bu sürecin ne şekilde formüle edileceği ise uygulama süreci yetkilisine bağlıdır ve kaçınılmaz olarak etkin ve yetkin bir kurumsal kapasite gerektirmektedir. Çünkü, ancak bu şekilde etkin kaynak kullanımı ve toplumsal uzlaşmanın sağlanması ve güç ilişkilerinin üstesinden gelinmesi mümkündür (Albrechts, 2004; Gupta vd., 2010). Gözden kaçırılmaması gereken en önemli noktalardan biri de, böylesi güçlü bir kurumsal kapasite yaratmanın zorluğu yanı sıra kurumun bu kapasiteyi işletebilecek finansal kaynaklara sahip olup olmadığıdır (Rydin ve Pennington, 2000).

Geniş perspektiften bakıldığında kentsel dönüşüm eylemi bir politikanın sonucudur. 6306 sayılı yasada belirtildiği gibi hedef afet riskli konut alanları öncelikli olmak üzere tüm konut alanlarında daha sağlıklı, kentsel kalitesi daha yüksek ve afetlere karşı daha dayanaklı konut alanları elde etmektir (R.G. 28309, 20I2). Hedeften yola çıkıldığında, politika yapıcıların afet riskli kentsel alanlar öncelikli olmak üzere, parsel ölçeğinde dönüşümden ziyade alansal ölçekte dönüşümü öne çıkardıklarını söylemek yanlış olmaz. Burada temel bir problemle karşılaşılması mümkündür. $O$ da politika yapıcıların öncelikleri ile yürütme sürecinde yetki devri yaptıkları yerel yönetimler arasındaki öncelikler çatışmasıdır (Hajer, 2003). Uygulama yürütücüsünün kurumsal kapasitesi uygulama alanındaki aktörler ve onların hem politika yapıcının geniş bağlamda ele aldığı ve kurguladığı genel politikayla hem de birbiriyle çelişebilen taleplerinden kaynaklanan (Memon vd., 2007) öncelikler çatışmasını hangi potada eriteceği ve buna gidecek süreçte yaratacağı fikri tartışma düzleminin belirleyicisidir. Kurumsal kapasite ve yapabilirlik hedeflenen politikadan uzaklaşmadan, ancak talepleri de ihmal etmeden, yerel düzlemde yeniden geliştirme modellerinin üretilmesi, bu modellere karşılık veren planlama araçlarının tartışıması ve geliştirilmesi ve politika yapıcıyla uzlaşmanın sağlanmasında esas unsurlar olmaktadır. Bu bağlamda, yürütme süreci yetkili kurumların kapasite yaratmaları gerekliliği basit iş ve işlemlerin yürütülmesi hedefinin çok ötesinde bir gerekliliktir.

\section{Kentsel Dönüşüm Uygulamalarında Kurumsal Kapasite Yaratma: Dünya Örnekleri}

Kentsel dönüşümü bütünleşik ve geniş katılımlı bir süreç olarak algılayan ve toplumsal faydayı bireysel faydanın önünde gören uygulama örneklerinden Grainger Town - Newcastle (İngiltere), Johannesburg (Güney Afrika Cumhuryeti) ve Shenzhen (Çin) örnekleri incelenmiştir. Grainger Town geniş katılımlı bütünleşik eylem yönetimi kurgusuyla kurumsal kapasite yaratılmasına örnektir. Johannesburg, potansiyelleri doğrultusunda aktör katılımını hedefleyen, toplam yetkinliği yüksek kurumsal yapı yaratılmasına örnektir. Shenzen ise teknokratik süreç işletimi ile bütünleşik ve geniş katılımlı kentsel dönüşüm eylemi arasında uyum ve entegrasyonu sağlama kabiliyetine sahip kurumsal kapasite yaratımına örnektir.
New Castle Grainger Town örneği kentsel dönüşümün bütünleşik bir eylem olarak yönetimini hedefleyen; bu hedef doğrultusunda kurumsal kapasite yaratmak üzere fikri platformu oluşturan ve bunu eyleme geçiren örnektir. Grainger Town örneğinde kentsel dönüşüm; geniş katılımlı, bütünleşik, dönüşüm eylemini süreç planlaması ile yönlendiren ve yürüten, kurumsal yapabilirlik ve yetkinliğe sahip kurumlar yoluyla dönüşüm sürecindeki aktörleri tanımlayan ve aktörlerin katııımını farklı modellerle sağlayan, kaynak kullanımını planlanan süreç bağlamında modelleyen, kendi kendini monitör edebilen ve yapısal problemleri olduğu anda çözerek süreç yönetiminde etkinliğini koruyan ve başarıyı sağlayan bir eylemler bütünü olarak tanımlanmıştır. Bu tanımlama aynı zamanda bir dönüşüm modeli tanımıdır ve bu modele göre çok katmanlı ve geniş katılımlı bir süreç yönetimi esastır. Süreçte rol alabilecek tüm aktörlerin görüş ve beklentilerinin alınması, aktörler arası uzlaşmazlıkların çözümü, kaynak aktarımının yapılacağı aktörler, bu aktörlerin diğer paydaşlar tarafından denetlenebilmesi amacıyla bilgi ve iletişim kanallarının açılması, dönüşüm eylemini yürütecek kurumun kaçınılmaz görevleridir. Özet olarak, kurumsal kapasite, kurumun sahip olduğu insan kaynakları ve donanımı ötesinde, politik ve sosyal ağlar ile yaratılan bilgi kaynakları ve kurumsal öğrenme yoluyla kendini sürekli yenileyen ve geliştiren bir kurumsal yapıyı tanımlamaktadır. Bu yapıda kurum, süreç yönetimini örgütleyen, toplumun farklı kesimlerinin tümünü kapsayan ve farklılıkları ayrıştırmayan, yatırımcıları bu çok paydaşlı ve çeşitliliği yüksek zeminde hareket etmeleri konusunda sürekli motive eden özelliktedir. Tüm bunları yapabilmek ancak güçlü bir sosyal sermayenin varlı̆̆ı ve iletişim ağ ve kanalları ile mümkün olacaktır. Dolayısıyla kurum denilen şey toplum bütününden ve dinamiklerinden bağımsız çalışan bir yapı değil tam tersine gücünü ve kapasitesini bunlardan alan bir yapıdır (Healey vd., 2002).

Güney Afrika Cumhuriyeti Johannesburg şehri örneğinde kurumsal kapasite yaratma yönündeki modelin çıkış noktasını 'kentsel dönüşüm eylemi planlamanın uzman ve teknik elemanları ile bürokratlarının eline bırakılamaz' görüşü oluşturmuştur (Thwala, 2009). Karar geliştirme ve karar verme süreçlerinde merkezi yaklaşımın yerine yerel aktörlerin katılımı esas alınmıştır. Dönüşüm eylemi, bu eyleme konu olan aktörler bağlamında tanımlanmış ve kurumsal kapasitenin bu doğrultuda yaratılması hedeflenmiştir. Buna göre, dönüşüm eyleminin başarısı, tüm aktörlerin sürece katılımına, süreç içinde aktörlere tanımlanan roller ve sorumluluklara bağlıdır. Sorumluluklar ne oranda yüksek olursa katılımın ve süreç içindeki aktör etkinliğinin yüksek olacağı savunulmuştur. Bunun başarılabilmesi ise bu süreci yönetebilecek toplam yetkinliği yüksek bir kuruma bağlıdır.

Buna ilaveten, kurumlar arası entegrasyon ve proje yönetiminde uzmanlaşmanın da dönüşüm uygulamalarında başarının temel unsuru oldukları savunulmuş, bunu gerçekleştirmek üzere 
de teknoloji kullanımını ve sosyal sermayeyi öne çıkaran bir yapılanmanın kurulması gerektiği görüşü ile kurumsal kapasite yaratılmaya çalışılmıştır. Bu görüşün bir önemli yanı da şudur: sosyal sermaye sadece ekonomik ve sosyolojik olarak güçlüleri değil, toplumsal zayıfları (kadınlar ve yoksullar gibi) da kapsar yapıda olmalıdır. Ötesinde, dönüşüm sürecinde kaynak dağılımı bu anlayış üstünden yapılmalıdır. Bu durumun kentsel dönüşüm eylemi sürecinde toplumsal mutabakatın sağlanmasında mutlak koşul olduğu kabul edilmiştir. Bir diğer önemli nokta da eylemin toplumun farklı kesimlerine maliyetinin ortaya konması gerektiği ve maliyetler konusunda da toplumun farklı katmanları arasında uzlaşma sağlanması gerektiğidir. Kaynak dağılımı nasıl farklı güçlere sahip aktörleri kapsıyor ve toplumsal zayıfları gözetiyorsa, maliyetlerin dağıımında da toplumsal zayıflar gözetilmeli ve maliyetin yüklenicileri haline gelmemelidirler (Thwala, 2009).

Çin'in Shenzhen şehri örneği ilk iki örnekten farklılaşmaktadır. Kentsel dönüşüm eylemi için bürokratik yapıda ve süreç işletimi teknokratik bir kurumsal kapasite yaratılmıştır. Teknokratik süreç işletimi için dört adım tanımlanmıştır. Bu dört adımda öncelikle fikri bir tartışma platformu oluşturmak üzere kentsel dönüşüm eylemi kavramsal olarak tartışılmış, dönüşüm eylemine dönük yasal düzenlemeler tartışmaların yön verdiği kavramsal zeminde kurgulanmıştır. Yasal düzenlemelerin hedefi teknokratik işletme süreci ile bütünleşik ve geniş katılımIı kentsel dönüşüm eylemi arasında uyum ve entegrasyonun sağlanmasıdır. Bu entegrasyonda ülkenin planlama eylemindeki kültür ve bilgi birikimi güçlü yan olarak kullanılmış, akademi kavramsal tartışmalar ve geliştirdiği modellerle entegrasyonda bağlaç rolünü görmüştür. Katı bürokratik ve teknokratik yapı rasyonel, bütünleşik, geniş katılımlı ve uzlaşmacı bir dönüşüm sürecini yürütecek şekilde uyumlandırılmıştır. Teknokratik süreç işletimi kentsel dönüşüm sürecinde tüm paydaşların katılımını hedefleyen ve sağlayan, tüm katmanların görüş ve beklentilerini ortak platformda geniş katılımlı toplantılar yoluyla olmasa da yüz yüze telefon görüşmeleri yoluyla alan, alınan talep ve görüşleri teknokratlar yoluyla değerlendiren ve stratejileri oluşturan, oluşturulan stratejileri katmanlara geri dönerek onlarla paylaşan ve görüşler doğrultusunda gözden geçirerek yeniden kurgulayan bir yapıdadır. Süreç işletimi teknokratik olmakla birlikte aktör katılımını önceleyen ve eylemin ortak kararlar bütünü çerçevesinde gerçekleşmesini sağlayan bir yapıdadır. Bürokratik yapı tüm bu teknokratik süreci işletecek kararlılık ve ekonomik güce sahip olmalıdır (Yi vd., 2017).

Özet olarak, farklı demokratik geleneklere sahip üç örneğin ortak özelliği kentsel dönüşümü dar anlamıyla fiziki bir eylem olarak değil geniş anlamıyla ele almalarıdır. Buna göre kentsel dönüşüm yereldeki tüm kaynak ve değerlerin saptanmış hedef doğrultusunda planlama yoluyla dönüşümüdür. Her üç örnekte de, çok boyutlu ve çok yönlü etkileri olan bu eylemin başarı ölçütü bütünleşik yapıdaki stratejik vizyon yönetimidir (Amin ve Tharift, 1995). van der Berg ve Brawn (1999)'ın önerdiği şekilde, karar geliştirme ve karar alma süreçlerinde yerel aktörler yüksek sorumluluğa sahiptir ve tümünün sürece etkin katılımları yoluyla toplam başarı artırılabilmiştir. Bu çok boyutlu stratejik eylemin yürütülmesi ve aktörlerin süreç entegrasyonu Alexander (2006)'ın vurguladığı gibi toplam yapabilirliği yüksek ve hedef alınan konu ya da problem doğrultusunda kurgulanmış kurumlar ile sağlanmıştır. Bu kurumlar (Healey vd., 2003)'in belirttiği gibi, bütünü oluşturan aktörleri harekete geçirebilme potansiyeline sahip yapıda kurumlardır.

\section{Kentsel Dönüşümde Kurumsal Kapasite Yaratma: Türkiye Örneği}

6306 sayılı Yasa beraberinde getirdiği yetki devirleri ile kentsel dönüşüm uygulamalarını yerel yönetimlere bırakmıştır. Ancak bu yetki devrinde uygulama sürecine ilişkin yerel yönetimlerin kendilerini nasıl yapılandıracakları konusunda yasada bir önerme olmadığı gibi fikri zeminde herhangi bir tartışma da yapılmamıştır. Dünya örneklerinde görüldüğü şekilde bir süreç yönetimi ve bunu gerçekleştirecek kurumlarda kapasite yaratılması konusu gündem oluşturmamıştır. Süreç doğrudan yerel yönetimlerin inisiyatiflerine bırakılmıştır.

Bu durumu uygulama sürecini yürütenler bakımından anlayabilmek ve yansıtmak üzere üç farklı yerel yönetim ile yüz yüze görüşmeler yapılmıştır. Görüşmeler Mart-Nisan 2017 tarihleri arasında ve kaynak yerinde gerçekleştirilmiştir. Üç örneğin seçimi rasyonel analitik kriterlere dayanmaktadır. Derinlemesine mülakatların yapıldığı üç büyük şehir belediyesi: gerek Toplu Konut İdaresi gerekse farklı kurum ve kuruluşlarla kentsel dönüşüm projeleri yürüten Kocaeli Büyük Şehir Belediyesi; dar anlamıyla ele alındığında kentsel dönüşüm uygulamalarının kentsel fiziki mekan üstünde yaratabileceği olumsuz etkilerin ulaşabildiği boyutun Doğanbey Mevkii dönüşüm uygulaması örneğinde izlenebildiği Bursa Büyük Şehir Belediyesi; ve kentsel dönüşüm projelerinde üniversite ile işbirliğine giden Eskişehir Büyükşehir Belediyesi'dir (Tüfekçi, 20I7).

Kocaeli Büyük Şehir Belediyesi ve Bursa Büyük Şehir Belediyesi bünyesindeki Kentsel Dönüşüm Şube Müdürlükleri, İmar ve Şehircilik Daire Başkanlığına bağı olarak ve 5393 sayılı Belediye Kanunun 73. Maddesine dayanılarak kurulmuştur. Her iki örnekte de Kentsel Dönüşüm Şube Müdürlükleri faaliyetlerini 5393 sayılı Kanunun 73. Maddesi uyarınca gerçekleştirmektedirler. Eskişehir Büyük Şehir Belediyesi Kentsel Dönüşüm Daire Başkanlığı 2014 yılına kadar İmar ve Planlama Daire Başkanlığı bünyesinde faaliyet gösteren bir Şube Müdürlüğü iken; 2014 yılından sonra Daire Başkanlığı statüsüne geçmiştir. Bu açıdan Bursa ve Kocaeli örneklerinden farklılık göstermektedir. Kentsel Dönüşüm Daire Başkanlığı 5393 sayılı Kanunun 73. Maddesi ve 6306 sayılı Kanun uyarınca gerçekleştirilen ve/veya planlanmakta olan iş ve işlemleri yürüten birimdir (Tüfekçi, 20I7). 
Üç büyük şehir belediyesinin ilgili birimleri ile yapılan görüşmelerde:

- Kentsel dönüşüm mevzuatı uygulamalarını yürütmek üzere nasıl bir idari yapılanma düzeni oluşturdukları,

- Oluşturulan yapıda yetki ve sorumluluklarının nasıl belirlendiği,

- Kurum içerisindeki imar ve şehircilik gibi planlama esaslı diğer birimler ile entegrasyon ve işbirliği konuları

- Oluşturulan yapının gerçekleştirdiği faaliyetler, bu faaliyetlerin ölçek ve kapsamları ile bu süreçlerde rol alan paydaşlar,

- Bu birimlere ait insan kaynakları kapasitesi hakkında bilgi edinilmiştir (Tüfekçi, 20I7).

Üç yerel yönetimle yapılan mülakatların genel yapıyı anlamak için yetersiz olabileceği düşünülebilir. Ancak, farklı aktörler ile işbirliği içinde kentsel dönüşüm uygulamaları yürüten ve mülakat talebine olumlu cevap veren üç büyük şehir belediye yönetimi ile yapılan görüşmelerin, kentsel dönüşümde kurumsal kapasite yaratmanın önemi, yolu ve gerekliliği konusunda tartışma başlatabileceğine inanmaktayız.

\section{Mülakat Bulguları}

Mülakatlar, kentsel dönüşüm uygulamalarının büyük şehir belediyelerinin yönetim şeması içinde İmar ve Şehircilik Daire Başkanlığı altında ya Kentsel Dönüşüm Şube Müdürlüğü olarak (Kocaeli ve Bursa Büyük Şehir Belediyeleri) ya da Kentsel Dönüşüm Dairesi Başkanlığı olarak (Eskişehir Büyük Şehir Belediyesi) bürokratik yapının uzantısı birimlerce yürütüldüğünü göstermektedir. Bunlar, Alexander (2006)'ın vurguladığı şekilde, hedefteki planlama eylemine göre yapılandırılmış birimlerdir. Ancak, yapılan mülakatlar, üç büyük şehir belediyesi bünyesinde kurulmuş bu birimlerin kentsel dönüşüm uygulamalarını yürütecek güçlü kurumsal yapılar olmadığını göstermektedir. Güçlü bir kurumsal yapı, kentsel dönüşüm ile planlama disiplini arasındaki kavramsal ilişkiyi kurabilen (van der Berg ve Braun, 1999), bu kavramsal bütünleşme bağlamında kent ölçeğinde bütünleşik vizyon ve stratejileri ortaya koyan, uygulama politikalarını belirleyen, süreç aktörlerini tanımlayan ve aktörler arasında etkin iletişim ve işbirliğini sağlayan, aktörlerin süreçte aldıkları rolleri ve sürece hangi nokta(lar)da dahil olacaklarını belirleyen (Bons ve Spekking, 20I2), kamuözel sektör ilişkisini kuran, dolayısıyla, bütünü oluşturan aktörleri harekete geçirme kapasitesine sahip (Healey vd., 2003) yapıdır. Güçlü bir kurumsal yapı, kamu kaynaklarının akılcı kullanımı yönünde kaynak kullanım modelleri geliştiren, aktörler arasında kaynak dağılımının nasıl olacağını belirleyen ve tüm bunları yaparken kolektif faydanın birey faydasının önüne geçtiği bir sistemi yaratabilen kurumsal yapıdır. Oysa, her üç örnekte de görüldügü gibi, ilgili birimlerin yetki ve sorumlulukları bürokratik düzenin işleyişi doğrultusunda belirlenmiştir. Kapasite anlayışı ise yasanın çizdiği uygulama hükümlerini hedefteki alanda uygulayabilirliklerinden ibarettir. Diğer bir deyişle, kurumsal yapabilirlik kurumsal yetkinliğin (Gualini, 2017) önüne geçmiştir.

Yetki ve sorumluluklar açısından bakıldığında, Kocaeli ve Bursa Büyük Şehir Belediye’lerinde kentsel dönüşüm İmar ve Planlama İşleri Kentsel Dönüşüm Şubesi tarafından Şehir Planlama Birimi ile eşgüdüm içerisinde hazırlanarak, İmar ve Planlama Daire Başkanlığı üzerinden meclis kararlarına bağlanmaktadır. Eskişehir Büyük Şehir Belediyesi'nde ise hem Kentsel Dönüşüm Daire Başkanlığı hem de İmar ve Planlama Daire Başkanlığı kentsel dönüşüm uygulamaları gerekçesiyle imar planı değişikliği yapma yetki ve sorumluluğuna sahiptir. Buradan anlaşılacağı gibi temel hedef yetki devriyle gelen kentsel dönüşüm uygulama sürecinin bürokratik yapıya uygun biçimde yürütülmesidir. Diğer bir deyişle, ölçüt kurumsal yetkinlik olarak değil kurumsal yapabilirlik (Gualini, 2017) olarak belirlenmiştir. Bu durumun doğal sonucu olarak kentsel dönüşüm eylemi dar anlamıyla ele alınmakta ve bürokratik iş/işlemler olarak görülmektedir. Bu bağlamda, güçlü kurumsal kapasite algısı insan kaynağı, teknik kaynaklar, mali kaynaklar ve fiziksel kaynaklara indirgenmektedir. Sorun teknik eleman ihtiyacı olarak tariflenmekte, çözüm olarak kentsel dönüşüm birimleri için özel kadrolar açılmaya çalışılmakta ve taşeron firmalar ile hizmet alım sözleşmeleri yapılmaktadır. Oysa beklenen, bu birimlerin, kentsel dönüşüm gibi oldukça karmaşık ve çok aktörlü, beklenen sonuçları çok boyutlu olan bir planlama eyleminde sürecin rasyonel ve verimli işletilmesini sağlayabilecek; farklı kurum ve organizasyonlarla ve problem kapsamındaki aktörlerle ilişki ağlarını kurabilecek kapasitede; kendisini değişen dinamiklere sürekli uyumlandırabilecek dinamik yapıda birimler olmalarıdır.

Kurumsal yapabilirlik üstüne kurgulanmış bürokratik yapı teknokratik sürecin işleyiş biçimine de etkimiştir. Her üç büyük şehir belediyesi yaşayanların kentsel dönüşüm konusunda uygulamaya dönük sorularına karşılık vermeye çalışmaktadır. Ancak bu, belediyelerin kentsel dönüşüme dayalı stratejik vizyon ve hedefleri bağlamında yapılmadığı gibi; toplumun tüm farklı kesimlerini temsil eden katmanların uzlaşmasını hedefleyen, geniş katılımlı, süreci aktörleriyle birlikte modelleyen bir yapı olmaktan da uzaktır. Bürokratik yapı içinde yapılandırılan birimler, bireylerin genellikle rayiç bedel/hak sahipliği konularında yoğunlaşan münferit soru ve beklentilerine cevap ve öneriler geliştirmektedir. Genellikle hak sahiplikleri konusunda sıkışmış, dolayısıyla, bireysel fayda ve çıkarların toplumsal faydanın önüne geçtiği bu yapı, bürokratik yapılanma ve teknokratik anlayışın doğal sonucudur. Bu durum, yerel yönetimlerin planlama eylemleri doğrultusunda yıllara dayanan kurum kültürleri ile bağdaşan bir durumdur. Türk planlama sistemi 1980'li yıllara dek merkeziyetçi, 1980'lerden sonra yetki dağılımı ile yerel yönetimlerin güçlendiği, 2000'li yılların ilk on yılından itibaren yerel yönetimler karşısında merkezin yeni- 
den çok güçlendiği bir yapıda olmuştur ve planlama sürecinde toplumsal katılım bir eylem pratiği oluşturamamıştır. Ne toplumun farklı katmanları ne de piyasa aktörlerini aynı zeminde buluşturabilen bir planlama eyleminden bahsetmek mümkün değildir. Toplum ve aktörler planlama sürecinde dışsaldır. Ancak, özellikle 1980'lerin ortasından itibaren, piyasa aktörlerinin plan sonrası uygulama süreçlerinde etkili güçler olduklarını ve süreci kendileri lehine döndürecek şekilde plan kararlarının değiştirilmesi konusunda yaptırımlarının yüksek olduğunu uygulama örnekleri göstermektedir. Bu durum yerleşik bir kurum ve planlama kültürü halini almıştır. Kentsel dönüşüm sürecinin bu yerleşik kültür bağlamında işletildiğini söylemek yanlış olmayacaktır. 6306 sayılı yasa da bu kurum kültürünün bir ürünüdür. Teknokratik işletiş temelli bu kurumsal yapılandırma biçimleri Çin Shenzhen kenti örneğine benzemektedir. Ancak Shenzhen örneğinde teknokratik işletiş ile bütünleşik ve geniş katılımlı kentsel dönüşüm eylemi arasındaki entegrasyon hedefi kurumsal yapılandırmanın temelini oluşturmuştur. Dolayısıyla, teknokratik işletiş rasyonel, bütünleşik, geniş katılımlı ve uzlaşmacı bir kentsel dönüşüm sürecini yürütecek şekilde uyumlandırılmışır. Üç belediye örneğinde ise bu durumun ihmal edildiği görülmektedir. Katı teknokratik işletişin tek hedefi yasanın alanda uygulanabilirliğini olanaklı kılmaktır. $\mathrm{Bu}$ anlayış, Türkiye örneklerini, New Castle ve Johannesburg örneklerinden kesin çizgilerle ayırmaktadır.

6306 sayılı yasa, kentsel dönüşüm eylemini bireylerin hak sahipliği konusuna indirgeyen, geniş toplumsal katılım, toplumsal fayda ve toplumsal mutabakat konularını tamamiyle ihmal eden yapıdadır. Belediyelere göre, böylesine statik ve kentsel dönüşümü en dar kapsamıyla ele alan yasal düzenlemenin neden olduğu problem, yasanın yerel yönetimler ile bireyleri karşı karşıya getirmesidir. Mülakatlarda vurgulandığı şekliyle, yasa dar anlamıyla uygulamayı hedef almış olsa da yasanın uygulama hükümleri bireylerin hak sahipliği konusundaki beklenti ya da problemlerine karşılık vermemekte ya da muğlak durumlar yaratmakta bu da yerel yönetimleri zora sokmaktadır. İlgili birimlerce yapılmış olan bu problem tanımından da anlaşılacağı gibi kentsel dönüşüm ne kavram olarak ne de uygulama olarak içselleştirilememiştir. Aynı zamanda bu tanımlama, ilgili birimlerinin kendilerini kurumsal yapabilirlikleri doğrultusunda uygulama sürecinin etkin aktörü olarak gördüklerini göstermektedir. Kurumsal yetkinlik konusunu sorgulamadıklarını göstermektedirr. Bu durum aynı zamanda, kentsel dönüşümün nasıl kolayca dar anlamına indirgendiğinin, stratejik vizyon ve hedefler doğrultusunda kurgulanmış bir süreç yönetimi olmaktan ne kadar uzak olduğunun en açıklayıcı örneği olabilir. Kurumsal kapasite yaratma sürecinde en önemli etmenlerden biri şüphesiz diğer kurumlarla kaynak ve bilgi alışverişinin sağlanabilmesidir (Phelps ve Tewdwr-Jones, 1998). Kentsel dönüşümün geniş anlamıyla ele alınması ve uygulama sürecinin buna göre modellenmesi hem bu konuda uzman kişi ve kuruluşların akademik ve profesyonel katkılarının alınması yoluyla hem de aynı süreci yürüten ve kendi bilgi ve tecrübesini oluşturmuş diğer kurumlarla teknik bilgi paylaşımı yoluyla olabilir. Eskişehir Büyük Şehir Belediyesi örneği bu anlamda önem kazanmaktadır. Belediye, üniversite ile işbirliği içinde kentsel dönüşüm alanı projesini geliştirmiştir. Planlama süreci paydaşların katılımı ile yürütülmüş, geniş katılımlı toplantılar nihai planlara yön vermiştir. Kocaeli Büyük Şehir Belediyesi örneğinde ilgili birimin yetkileri arasında 'gerekli görüldüğü takdirde üniversitelerden ve diğer kamu kurum ve kuruluşlarından eğitim veya danışmanlık hizmetleri almak' ve 'bilgilendirici sempozyum ve toplantılar düzenlemek veya katılmak' vardır. Ancak belediyenin bu tanımlanan yetkileri etkin kullanmadığı anlaşılmıştır. Mülakatlardan çıkan bir diğer önemli sonuç, yerel yönetimlerin, uygulama sürecini yürüten diğer yerel yönetimler ile sürece dönük bilgi ve tecrübe paylaşımında bulunmamalarıdır. Kurum içi bilgi akışının sağlanması da bir diğer önemli konudur. Diğer iki örnekten farklı olarak, Eskişehir Büyük Şehir Belediyesi'nin kentsel dönüşüm alanları ile ilgili belediyenin diğer birimlerine bilgi akışı sağladığı, dönüşüm sürecine ilişkin eğitim seminerleri düzenlediği belirtilmiştir. Bu durum kurum kaynaklarının süreçte etkili kullanımının sağlanması bakımından önemlidir. Böylelikle, kurum içindeki farklı disiplinler teknik ve profesyonel bilgi birikimleriyle sürece dış bakış sağlamakta hem de süreç boyunca oluşabilecek olası problemlerin çözümünde hangi noktalarda katkı sağlayabileceklerini ortaya koymaktadırlar.

Kentsel dönüşüm uygulamalarının bireysel hak ve çıkarlar konusuna indirgendiği, uygulama problemlerinin teknik personel ve kaynak eksikliği konularında düğümlendiğini gösteren mülakatlar bu çok boyutlu ve çarpan etkisinin yüksek olduğu eylemin dar bir perspektiften ele alındığını göstermektedir. Uygulama süreçlerinin, aktör katılımlarını sağlamaktan uzak olduğu, dönüşüm uygulamalarının kaynak kullanımı ve yaratacağı sosyal, mekansal ve ekonomik etkileri bağlamında modellenip tartışılmadığı, uygulama süreci başarısının kurumsal yapabilirlik esasına bağlandığı, ancak, rasyonel süreç yönetimi ve kurumsal bilgi birikimi ve uygulama süreçlerinden kaynaklanan kurumsal hafızayı önceleyen kurumsal yetkinliği ihmal ettiği görülmektedir. Dolayısıyla, hedefteki planlama problemi bağlamında sürekli kendini yenileyebilen dinamik yapıdaki yetkin ve kapasitesi yüksek kurumlardan bahsetmek mümkün değildir. Süreci olması gerektiği gibi yürütecek kurumlar ve kurumsal kapasitenin oluşturulamadığı görülmektedir. Süreç, plan uygulama süreçlerinden alışılageldiği haliyle işletilmeye çalışılmaktadır.

\section{Genel Değerlendirme}

Kentsel dönüşüm yasası tüm kentleri ve kentler içinde yapılaşmış tüm alanları kentsel dönüşüme konu haline getirmiştir. Kentsel dönüşüm eylemi çok boyutlu, çok aktörlü, çok karmaşık bir eylemdir. Böylesi bir eylemin uygulama süreçleri de karmaşıktır; iyi analiz edilmiş ve buna göre modellenmiş bir 
süreç işletimi gerektirir. Bu süreci olması gerektiği gibi yürütecek yapılar kurumlardır. Kurumların kapasite ve yapabilirlikleri kentsel dönüşüm eyleminde başarının temel ölçütüdür. Kurumsal kapasite yaratmadan kentsel dönüşüm eyleminin başarıya ulaşmasını beklemek mümkün değildir.

Uygulama sürecinin başarı ölçütü olan güçlü kurumsal kapasite neyi yapabilir kılar? Bu soruya verilecek cevap kurumsal kapasitenin neden önemli olduğunu da yansıtacaktır. Güçlü bir kurumsal kapasite: kentsel dönüşümü geniş anlamıyla tartışarak bu tartışmalar doğrultusunda kurum vizyon, strateji ve politikalarını belirleyebilecek, planlamayla entegrasyonu sağlayabilecek; aktörlerin katılımı ve süreç içindeki rol tanımları doğrultusunda kentsel dönüşüm planlama ve uygulama süreçlerini modelleyebilecek; kentsel dönüşüm uygulamalarına dönük plan uygulama araçlarını tanımlayabilecek; dönüşüme dönük kaynak kullanımında ve kaynak dağııımında aktör ve toplumun paydaşlarıyla birlikte karara varabilecek; toplumsal faydayı bireysel faydanın önüne geçirebilecek; geniş katılımlı, bütünleşik bir eylem gerçekleştirebilecek yapıyı tarifler.

Türkiye örneğine bakıldığında, kentsel dönüşüm eylemlerini yürüten kurumların kapasite yaratmaktan uzak olduğu görülmektedir. Kentsel dönüşüm eylemi planlama ile entegrasyonu sağlanmamış, parçacı, birey çıkarlarını önceleyen, birey katılımına açık ancak geniş toplumsal katılım ve uzlaşmayı sağlamaktan uzak, kaynak kullanımında rasyonel olmayan, sadece fiziki planlamayı dikkate alan, olası toplumsal, ekonomik ve mekânsal etkileri inmal eden, kümülatif sonuçları belirsiz bir eylem halini almıştır. Kentsel dönüşüm süreci bürokratik yapıda, statik ve teknokratik işletiş ile yürütülmektedir. Eylem ve yürütülme biçimi uyumlu olsa da bunun kentsel dönüşüm kavramı ile örtüştüğü söylemek mümkün değildir.

Tüm kentlerin ve tüm kentsel mekanların dönüşüme aday olduğu böylesi bir yapıda, hem uygulama süreci hem de sonuçları çok boyutlu dönüşüm eyleminin kurumsal yapabilirlik anlayışı ile ele alınması en büyük problemdir. Kurumsal yetkinliğe dayalı güçlü kurumsal yapı anlayışı oluşamamıştır. Kurumsal kapasitesini yaratamamış kurumlar tarafından yürütülen ve bağlamından koparılmış kentsel dönüşüm süreçlerinin, kaynak kullanımı bakımından verimsiz, sürecin aktörlerini dışsal alan, kamu erkini önceleyen, dolayısıyla toplumsal fayda ve adaletin tesisini sağlayamayan, çevre duyarlı ve yüksek nitelikli kentsel mekânların yaratılması gibi temel planlama prensiplerini ihmal eden uygulamaları beraberinde getirmesi kaçınıımazdır. 


\section{KAYNAKLAR}

Albrechts, L. (2004). Strategic (spatial) planning reexamined, Environment and Planning B: Planning and Design, 31, 743-758.

Alexander, E.R. (2006). Institutional Design for Sustainable Development, The Town Planning Review, 77( 1), 1-27.

Amin, A. and Thrift, N. (1995). Globalization, institutional thickness and the local economy, Ed. P. Healey, S. Cameron, S. Davoudi vd, Managing Cities , 91-108, London: John Wilev and Son.

Boons, F., Spekking, W. (2012). Levels of Institutional Capacity and Actor Expectations about Industrial Symbiosis Evidence from the Dutch Stimulation Program 1999-2004, Journal of Industrial Ecology, 16(1), 61-69.

Buitelaar, E., Lagendijk, A., Jacobs, W.A.A. (2007). A theory of institutional change : illustrated by Dutch city-regions and Dutch land policy, Environment and Planning A, 39(4), 891-908.

de Magalhaes, C.S. (2004). Centres of Excellence for Urban Regeneration: Promoting Institutional Capacity and Innovation or Reaffirming Old Ideas?, Planning Theory and Practice, 5(1), 33-47.

Gualini, E. (2017). Institutional Capacity Building as an Issue of Collective Action and Institutialisation: Some Theroretical Remarks, Ed. G. Cars, P. Healey, A. Madanipour ve C. De Magalhaes, Urban Governance, Institutional Capacity and Social Mileux, 29-45, Routledge.

Gupta, J., Termeer, C., Klosterman, J., Meijerink, S., van der Brink, M., Jong, P., Nooteboom, S., Bergsma, E. (2010). The Adaptive Capacity Wheel: a method to asses the inherent characteristics of institutions to enable the adaptive capacity of society, Environmental Science Policy, 13, 459-471.

Hajer, M. (2003). A frame in the fields: policymaking and the reinvention of politics, Ed. M. Hajer ve H. Wagenaar, Deliberative Policy Analysis: Understanding Governance in the Network Society, 88-110, Cambridge University Press.

Healey, P. (1991). Urban regeneration and the development industry, Regional Studies, 25, 97-11

Healey, P., de Magalhaes, C., Madanipour, A., Pendlebury, J. (2002). Shaping City Centre Futures: Conservation, Regeneration and Institutional Capacity Regeneration in Grainger Town, Newcastle, CRUE (Centre for Research in European Urban Environments: Newcastle-upon-Tyne) Working Papers, University of Newcastle.

Healey, P., de Magalhaes, C., Madanipour, A., Pendlebury, J. (2003). Place, identity and local politics: analysing initiatives in deliberative governance, Ed. M. Hajer ve H. Wagenaar, Deliberative Policy Analysis: Understanding Governance in the Network Society, 60-87, Cambridge University Press.

Innes, J.E., Booher, D.E. (2004). Reframing public participation: strategies for the 21st century, Planning Theory and Practice, 5(4), 419-436.

Memon, A., Davies, T.G., Fookes, T. (2007). Institutional arrangements for metropolitan government and strategic planning in Auckland, New Zeland Geographer, 63, 43-54.

Moulaert, F., Martinelli, F., Swyngedouw, E., Gonzales, S. (2005). Towards Alternative Model(s) of Local Innovation, Urban Studies, 42(11), 1969. 1990.

Phelps, A., Tewdwr-Jones, M. (1998). Institutional capacity building in a strategic policy vacuum: the case of the Korean company LG in South Wales, Environment and Planning C: Goverment and Policy, 16, 735-755.

Resmi Gazete (2012). Resmi Gazete No. 28309, Tertip: 5, Cilt: 52, $31 / 05 / 2012$

Rydin, Y., Pennington, M. (2000). Public Participation and Local Environmental Planning: The collective action problem and the potential of social capital, Local Environment, 5(2), 153-169.

Thwala, W. D. (2009). Experiences and Challenges of Community Participation in Urban Renewal Projects: The Case of Johannesburg, South Africa, Journal of Construction in Developing Countries, 14(2), 37-54.

Tüfekçi, Y. (2017). Kentsel Dönüşüm: Yerel Yönetimlerin Kentsel Dönüşüm Mevzuatına Yönelik Kurumsal Yapılanma ve Kapasiteleri, İTÜ Fen Bilimleri Enstitüsü, Şehir Planlama Programı, Basılmamış Y. Lisans Tezi (Danışman: Doç. Dr. Elif Alkay) van der Berg, L. \& Braun, E. (1999). Urban Competitiveness, Marketing and the Need for Organising Capacity, Urban Studies, 36(5/6), Review Issue: Competitive Cities, 987-999.

Yi, Z., Liu, G., Lang, W., Shrestha, A., Martek, I. (2017). Strategic Approaches to Sustainable Urban Renewal in Developing Countries: A Case Study of Shenzhen, China, Sustainability, 1469(9), 1-19.

Zhao, P. (2015). The evolution of the urban planning system in contemporary China: an institutional approach, IDPR, 37(3), 269-287. 